Vol. 7 (1998): 491-505.

\title{
Effect of soil wetness on air composition and nitrous oxide emission in a loam soil
}

\author{
Antti Jaakkola and Asko Simojoki \\ Department of Applied Chemistry and Microbiology, PO Box 27, FIN-00014 University of Helsinki, \\ Finland, e-mail: antti.jaakkola@helsinki.fi
}

\begin{abstract}
Effects of cropping (bare fallow, grass), heavy irrigation and $\mathrm{N}$ fertilization $\left(0,100 \mathrm{~kg} \mathrm{ha}^{-1}\right)$ on soil air (at depths of 15 and $30 \mathrm{~cm}$ ) and $\mathrm{N}_{2} \mathrm{O}$ emission were studied in a factorial two-year field experiment in southern Finland. The responses of soil mineral N, dry-matter yield and uptake of N were also determined. Irrigation was performed during two periods in 1993 and one period in 1994. During sampling periods, the soil moisture ranged from $11 \%$ to $45 \%(\mathrm{v} / \mathrm{v})$ and soil temperature from $0^{\circ} \mathrm{C}$ to $21^{\circ} \mathrm{C}$. Unirrigated bare fallow contained $14-21 \% \mathrm{O}_{2}, 0.1-2 \% \mathrm{CO}_{2}$ and $0.2-100 \mu 11^{-1} \mathrm{~N}_{2} \mathrm{O}(1993$ maximum $27 \mu \mathrm{l}^{-1}$ ) in the soil air. Cropping and irrigation lowered $\mathrm{O}_{2}$ (minimum 3-7\%) and raised $\mathrm{CO}_{2}$ (maximum 9\%) in soil air, but fertilization had no effect. Irrigation raised $\mathrm{N}_{2} \mathrm{O}$ in the soil air if nitrate was present abundantly. Consequently, fertilization increased $\mathrm{N}_{2} \mathrm{O}$ especially in the irrigated bare soil, which still contained plenty of nitrate in autumn 1993. Cropping decreased $\mathrm{N}_{2} \mathrm{O}$. The variation in soil air composition was partly explained by that in soil air-space. The average daily $\mathrm{N}_{2} \mathrm{O}-\mathrm{N}$ emission amounted to $0-40 \mathrm{~g} \mathrm{ha}^{-1}$ (mean $7 \mathrm{~g} \mathrm{ha}^{-1}$ ) and correlated positively with $\mathrm{N}_{2} \mathrm{O}$ concentration in the soil air.
\end{abstract}

Key words: carbon dioxide, denitrification, oxygen, soil air composition

\section{Introduction}

Soil moisture affects the gas composition of soil air in different ways. Soil organisms affected by moisture consume and produce gases which alter the composition of soil air. Such changes are counteracted by the gas exchange between the soil and the atmosphere. Increasing moisture causes decreasing air content. Because gases are conducted almost entirely through air-filled pores, gas exchange between the atmosphere and soil pores will slow down with increasing moisture.

Excess soil moisture is known to be detrimental to the growth of various field crops. The change in soil air composition may play an important role (Glínski and Stępniewski 1985). Low $\mathrm{O}_{2}$ concentration in soil air has been shown to retard plant growth independently of soil wetness in experiments where soil air composition is artificially regulated (e.g. Jaakkola et al. 1990).

Soil air composition has been measured in a few field studies in the Nordic countries (Lind- 


\section{AGRICULTURAL AND FOOD SCIENCE IN FINLAND}

Jaakkola, A. \& Simojoki, A. Effect of wetness on soil air

$\mathbf{N}$
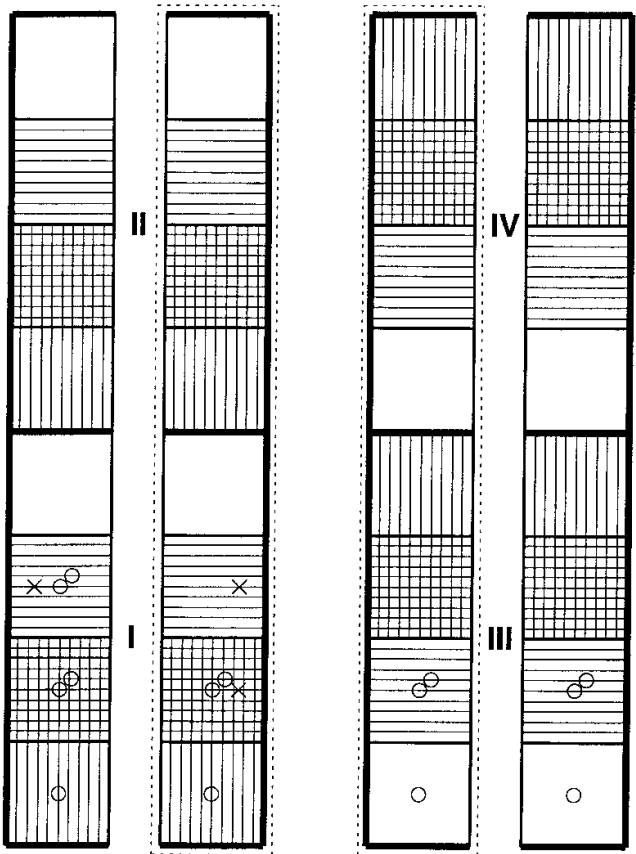

$\||||| \operatorname{Crop}\left(\mathrm{C}_{1}\right)$

$\mathrm{N} 100 \mathrm{~kg} \mathrm{ha}^{-1}\left(\mathrm{~N}_{1}\right)$

Irrigation $\left(l_{1}\right)$

$\times \quad$ Pt100 probe

- $\mathrm{N}_{2} \mathrm{O}$ emission

chamber

$3 \mathrm{~m}$

Figure 1. Treatments, temperature probes and emission chambers on the experimental field.

ström and McAfee 1989, McAfee et al. 1989a,b, zons $\mathrm{Ap}, \mathrm{Bw}$ and $\mathrm{Cg}$ at depths $0-30,30-90$ and below $90 \mathrm{~cm}$, respectively. On the average, the topsoil contained $2.4 \%$ organic carbon and $0.15 \%$ total nitrogen, and its $\mathrm{pH}\left(\mathrm{CaCl}_{2}\right)$ was 7.2. The average particle-size composition was: $17 \%$ clay $(0-2 \mu \mathrm{m}), 47 \%$ silt $(2-20 \mu \mathrm{m})$ and $24 \%$ very fine sand $(20-60 \mu \mathrm{m})$. The field had been under normal plant production for decades, producing in most years cereals, grass and sugar beet. $\mathrm{Au}-$ tumn ploughing had been the common practice for basic tillage.

The field experiment was set up in spring 1993 (Fig. 1). Treatments involving the following experimental factors were replicated four times:

\section{Material and methods}

A field experiment was performed in 1993-94 in southern Finland $\left(60^{\circ} 46^{\prime} \mathrm{N}, 24^{\circ} 55^{\prime} \mathrm{E}, 105 \mathrm{~m}\right.$ asl). The soil was Aquic Cryochrept with hori-

Soil wetness: not irrigated $\left(\mathrm{I}_{0}\right)$; irrigated $\left(\mathrm{I}_{1}\right)$ Cropping: bare fallow $\left(\mathrm{C}_{0}\right)$; cropped with cereal-grass mixture $\left(\mathrm{C}_{1}\right)$

$\mathrm{N}$ application: not applied $\left(\mathrm{N}_{0}\right) ; 100 \mathrm{~kg} \mathrm{ha}^{-1}$ $\mathrm{N}$ at the start of experiment $\left(\mathrm{N}_{1}\right)$ 
Vol. 7 (1998): 491-505.

Fertilization and sowing was performed on 24 May 1993, with a combine drill being used to place the fertilizer (calcium ammonium nitrate) in rows $25 \mathrm{~cm}$ apart and $8 \mathrm{~cm}$ deep in the middle of every second sowing-row interval. The seed consisted of a mixture of winter rye (Secale cereale), Italian rye grass (Lolium multiflorum), Persian clover (Trifolium resupinatum), timothy (Phleum pratense) and meadow fescue (Festuca pratense). Plants from the bare fallow plots were removed by hand as they emerged.

Using a tractor-mounted sprayer producing approximately $10 \mathrm{~mm}$ water per hour, the ploughed layer was saturated with water during three periods at different stages of the growing season. In 1993 the field was irrigated with 120 $\mathrm{mm}$ of water between 15 June and 2 July, and with $110 \mathrm{~mm}$ of water between 27 July and 10 August. In $199484 \mathrm{~mm}$ of water was given during 18-22 August.

Porous cups made of sintered polyethylene (pore size $\varnothing 100 \mu \mathrm{m})$, one for each depth (15 and $30 \mathrm{~cm}$ ), were inserted into holes made in each plot with an auger $(\varnothing 3 \mathrm{~cm})$ immediately after sowing and fertilization. The air-filled space around and inside the cup was about $20 \mathrm{ml}$. Sampling of soil air was performed about once a week during the growing period of 1993 and about once a fortnight during the growing period of 1994, mostly between 6 and 8 p.m. A 4 ml sample was taken with a glass syringe through a silicon rubber septum connected to the cup with a narrow Teflon tube (volume approximately $1 \mathrm{ml}$ ). After discarding the first sample, $5 \mathrm{ml}$ was taken for analysis in the same way. The air samples were stored for no more than two days in the glass syringes and then analyzed for $\mathrm{N}_{2}, \mathrm{O}_{2}, \mathrm{CO}_{2}$, $\mathrm{CH}_{4}, \mathrm{C}_{2} \mathrm{H}_{4}$ and $\mathrm{N}_{2} \mathrm{O}$. Two interconnected gas chromatographs (Hewlett Packard 5890) were used. One of them was equipped with a Molecular Sieve 5A packed column $(1.8 \mathrm{~m})$ for $\mathrm{N}_{2}$, $\mathrm{O}_{2}+\mathrm{Ar}, \mathrm{CH}_{4}$ and $\mathrm{C}_{2} \mathrm{H}_{4}$ and a Porapak Q packed column $(1.8 \mathrm{~m})$ for $\mathrm{CO}_{2}$. Helium was the carrier gas $\left(35 \mathrm{ml} \mathrm{min}^{-1}\right)$. The oven temperature was $80^{\circ} \mathrm{C}$. The detectors $\left(200^{\circ} \mathrm{C}\right)$ were $\mathrm{TC}$ for $\mathrm{N}_{2}$, $\mathrm{O}_{2}+\mathrm{Ar}$ and $\mathrm{CO}_{2}$, and $\mathrm{FI}$ for $\mathrm{CH}_{4}$ and $\mathrm{C}_{2} \mathrm{H}_{4}$. The other GC had a Porapak Q packed column $(1.8 \mathrm{~m})$ and an $\mathrm{EC}$ detector $\left(300^{\circ} \mathrm{C}\right)$ for $\mathrm{N}_{2} \mathrm{O}$. The carrier $\left(95 \% \mathrm{Ar}, 5 \% \mathrm{CH}_{4}\right)$ flow was $35 \mathrm{ml} \mathrm{min}^{-1}$ and the oven temperature $40^{\circ} \mathrm{C}$. The Ar concentration in air was assumed to be $0.9 \%$ for calculating the $\mathrm{O}_{2}$ concentration. When calculating the results the sum of determined gas concentrations was adjusted to $100 \%$.

Steel cylinders, $16 \mathrm{~cm}$ in diameter and $25 \mathrm{~cm}$ in height, were inserted $10 \mathrm{~cm}$ deep into the soil in nine plots (Fig. 1) at the beginning of the experiment in order to monitor the emission of $\mathrm{N}_{2} \mathrm{O}$ from the soil. One cylinder was placed on each unfertilized plot, but two cylinders on each $\mathrm{N}$ treated plot in order to cover the fertilizer rows and the space between them representatively. At each sampling of the soil air each cylinder was covered with an air-tight rubber sheet for 40-60 min. The daily emission of $\mathrm{N}_{2} \mathrm{O}$ was calculated assuming a linear increase of gas concentration in the closed chamber from the measured mean ambient level $\left(0.322 \mu 11^{-1}\right)$ to the concentration measured at the end of sampling period.

Soil moisture in the 0-20 cm layer was monitored by TDR (Tektronix 1502B) plotwise in blocks I-III (Fig. 1) as often as the soil air was sampled. The soil temperature at depths of 15 and $30 \mathrm{~cm}$ was monitored with Pt100 probes in three plots (Fig. 1) in connection with air sampling.

Soil samples were taken at depths of $0-15$ $\mathrm{cm}$ and $15-30 \mathrm{~cm}$ from the area between unirrigated and irrigated plots on 15 June 1993, just before the first irrigation. The same soil depths were sampled on 4 July plotwise in the blocks I, II and III. All plots were sampled at the abovementioned depths on 2 September 1993. For determination of mineral nitrogen the samples were extracted with $2 \mathrm{M} \mathrm{KCl}$. Ammonium and nitrate in the extract were determined colorimetrically.

The plant stand was cut from the cropped plots on 1 September 1993 and 14 June 1994, taking plotwise a sample from an area of 0.45 and $0.25 \mathrm{~m}^{2}$, respectively. The plant samples were dried at $70^{\circ} \mathrm{C}$ and weighed. Total nitrogen was determined using the common Kjeldahl digestion procedure. 
Jaakkola, A. \& Simojoki, A. Effect of wetness on soil air

Table 1. Crop $\left(\mathrm{C}_{1}\right)$ yield and uptake of $\mathrm{N}$ in unirrigated $\left(\mathrm{I}_{0}\right)$ and irrigated $\left(\mathrm{I}_{1}\right)$, as well as in unfertilized $\left(\mathrm{N}_{0}\right)$ and fertilized $\left(100 \mathrm{~kg} \mathrm{ha}^{-1} \mathrm{~N}, \mathrm{~N}_{1}\right)$ soil.

\begin{tabular}{lcccc}
\hline & $\mathrm{C}_{1} \mathrm{I}_{0} \mathrm{~N}_{0}$ & $\mathrm{C}_{1} \mathrm{I}_{0} \mathrm{~N}_{1}$ & $\mathrm{C}_{1} \mathrm{I}_{1} \mathrm{~N}_{0}$ & $\mathrm{C}_{1} \mathrm{I}_{1} \mathrm{~N}_{1}$ \\
\hline Yield, D.M. kg ha & & & & \\
1993 & & & & \\
1994 & $1377^{\mathrm{a}}$ & $2736^{\mathrm{b}}$ & $2123^{\mathrm{ab}}$ & $3611^{\mathrm{c}}$ \\
Total & $4175^{\mathrm{a}}$ & $4472^{\mathrm{a}}$ & $3082^{\mathrm{a}}$ & $3821^{\mathrm{a}}$ \\
\hline${\mathrm{N} \mathrm{uptake,} \mathrm{kg} \mathrm{ha}^{-1}}^{5551^{\mathrm{ab}}}$ & $7207^{\mathrm{b}}$ & $5205^{\mathrm{a}}$ & $7431^{\mathrm{b}}$ \\
1993 & & & & \\
1994 & $35^{\mathrm{a}}$ & $83^{\mathrm{b}}$ & $37^{\mathrm{a}}$ & $79^{\mathrm{b}}$ \\
Total & $50^{\mathrm{a}}$ & $58^{\mathrm{a}}$ & $39^{\mathrm{a}}$ & $50^{\mathrm{a}}$ \\
\hline
\end{tabular}

Means in the same row followed by a common letter do not differ significantly $(\mathrm{P}=0.05)$

D.M. = dry matter

\section{Statistical analysis}

The treatments were partly arranged systematically in the blocks (Fig. 1). However, no systematic change in soil properties was apparent. Therefore, in comparing the treatments, an analysis of variance for a blockwise randomized design was made. In cases where the interactions were significant, individual treatment means were compared by Tukey's test. Correlation analysis was performed between the plotwise $\mathrm{N}_{2} \mathrm{O}$ emission data and corresponding $\mathrm{N}_{2} \mathrm{O}$ concentrations in the soil air.

In order to reduce the random variation of gas concentrations in the soil air samples, averages over three subsequent samplings were statistically analysed. Soil moisture data were analysed similarly. A logarithm transformation was used for the $\mathrm{N}_{2} \mathrm{O}$ concentrations to approach a normal distribution.

\section{Results}

Nitrogen application increased the crop yield and the $\mathrm{N}$ uptake in the first year (Table 1). Irrigation increased the first-year yield significantly only when nitrogen was applied. The nitrogen uptake did not respond to irrigation.

Mineral nitrogen in the top $30 \mathrm{~cm}$ of soil did not significantly respond to nitrogen application or cropping in the middle of June three weeks after fertilization and sowing (Table 2) although the mean concentration was generally higher in the fertilized plots. About three weeks later (4 July) nitrogen application resulted in a significant increase, while cropping had a decreasing effect. Only nitrate in the topmost layer (0$15 \mathrm{~cm}$ ) was affected. Irrigation did not have any effect. The crop reduced the nitrate concentrations in late summer (2 September), as did irrigation, but to a lesser extent. Nitrogen application still had a small increasing effect. Concentrations in the cropped soil were rather low.

Nitrogen application did not significantly affect the soil moisture or the response of soil air composition to other treatments. Therefore, averages over both $\mathrm{N}$ rates representing cropping and irrigation treatments are given in Figures 2 and 3, as well as in Tables 3, 4, 5 and 6.

Variations of soil temperature during both years were rather similar, considering the dissimilar observation periods (Fig. 2). The soil moisture varied during the first year between $16 \%$ and $44 \%$ in the non-irrigated soil. The soil was dry when the experiment started (beginning of June), gained moisture for a couple of weeks 
Vol. 7 (1998): 491-505.

Table 2. Mineral nitrogen in soil layers $0-15 \mathrm{~cm}$ and $15-30 \mathrm{~cm}, \mathrm{mg} \mathrm{kg}^{-1}$ D.M. Treatments: $\mathrm{C}_{0}$ bare soil, $\mathrm{C}_{1}$ cropped; $\mathrm{I}_{0}$ no irrigation, $\mathrm{I}_{1}$ irrigated; $\mathrm{N}_{0}$ no fertilizer, $\mathrm{N}_{1} 100 \mathrm{~kg} \mathrm{ha}^{-1} \mathrm{~N}$.

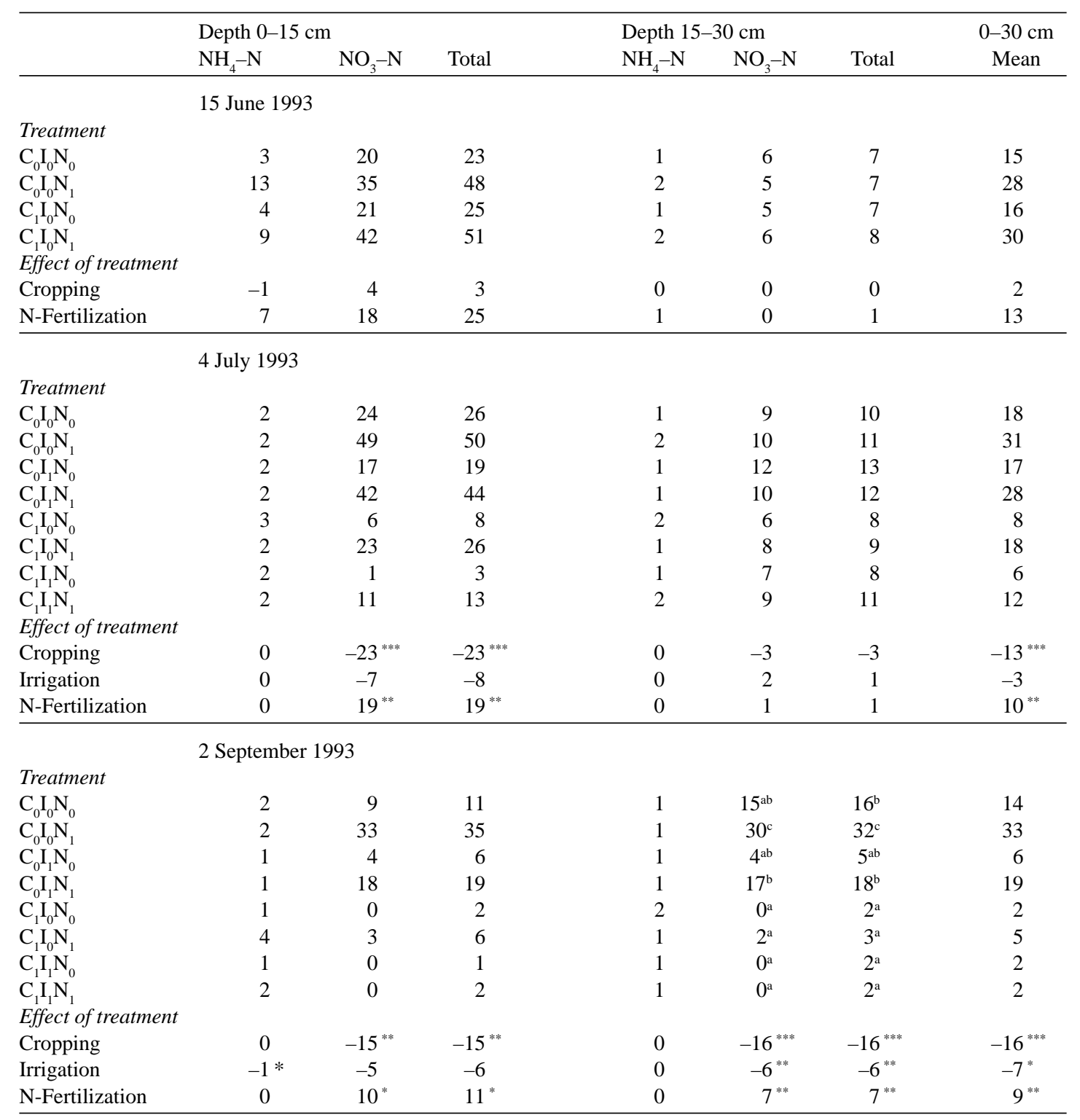

Means in columns with significant treatment interactions followed by a common letter do not differ significantly $(\mathrm{P}=0.05)$

Significance of effects: $*=\mathrm{P}<0.05, * *=\mathrm{P}<0.01, * * *=\mathrm{P}<0.001$

D.M. = dry matter

and dried again to the initial moisture level in July. Thereafter, due to rain, the soil became moister, reaching a maximum at the end of $\mathrm{Au}$ - gust. Irrigation raised the moisture content at most to $45 \%$, probably saturating the topsoil (0$20 \mathrm{~cm}$ ) at that time. The increases produced by 
Jaakkola, A. \& Simojoki, A. Effect of wetness on soil air

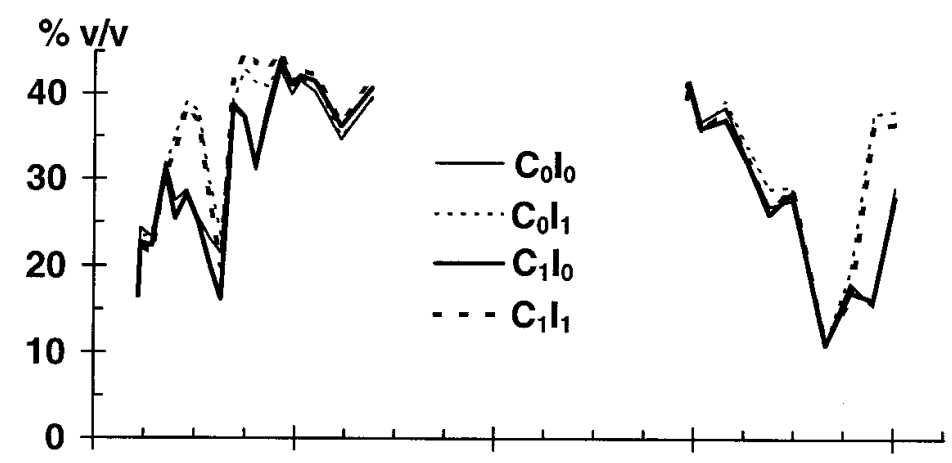

Figure 2. Soil moisture $0-20 \mathrm{~cm}$ (above), and soil temperature at depths of 15 and $30 \mathrm{~cm}$ (below). Daily precipitation (columns) was measured ca. $6 \mathrm{~km}$ north of the field (data provided by the Finnish Meteorological Institute).

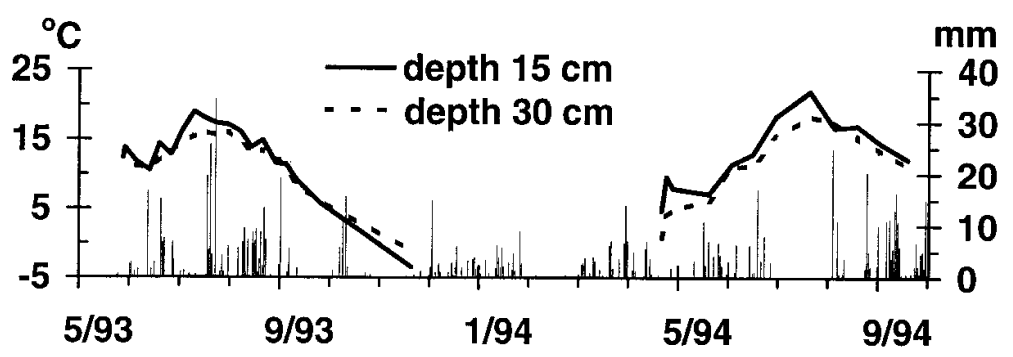

irrigation lasted 2-3 weeks beyond the irrigation periods. In the second year the field dried gradually until August, reaching a minimum of $11 \%$ moisture content. The very small and inconsistent difference in moisture between noncropped and cropped plots was not significant according to statistical analyses made when the effects of irrigation were greatest (Table 3 ).

Table 3. Average soil moisture (TDR measurement) in topsoil $(0-20 \mathrm{~cm})$ during various periods, and moisture increase due to treatments, $\% \mathrm{v} / \mathrm{v}$.

\section{6.-11.7.1993 1.8.-15.8.1993 22.8.-19.9.1994}

\begin{tabular}{lccc} 
Treatment & & & \\
Control & 25.8 & 35.0 & 26.9 \\
Irrigated & 35.5 & 41.7 & 38.3 \\
Cropped & 24.5 & 35.6 & 26.6 \\
Cropped + irrigated & 34.2 & 43.8 & 37.0 \\
Effect of treatment & & & \\
Cropping & -1.3 & 1.4 & -0.8 \\
Irrigation & $9.7^{* * *}$ & $7.4^{* * *}$ & $10.9^{* * *}$ \\
N-fertilization & -1.3 & -1.6 & -1.4 \\
\hline
\end{tabular}

Significance of effects: ${ }^{*}=\mathrm{P}<0.05,{ }^{*}=\mathrm{P}<0.01$, $* * *=\mathrm{P}<0.001$
In the first year $\mathrm{O}_{2}$ concentration in the air of unirrigated bare soil (control treatment, $\mathrm{C}_{0} \mathrm{I}_{0}$ ) varied between the ambient concentration and $14.4 \%$ (Fig. 3). The range of $\mathrm{CO}_{2}$ concentrations in that treatment was between $0.1 \%$ and $2.2 \%$.

Cropping decreased the $\mathrm{O}_{2}$ concentration and increased the $\mathrm{CO}_{2}$ concentration from July until the end of growing season (Fig. 3). The $\mathrm{O}_{2}$ decrease was not significant before the first half of August (Table 4). At that time the decrease was very marked under crop. The $\mathrm{CO}_{2}$ increase was significant already in July, but a marked increase was not apparent until early August under crop (Table 5). The largest differences in the first year were observed deeper in the topsoil $(30 \mathrm{~cm})$ near the end of August, when the $\mathrm{O}_{2}$ concentration dropped to $8.1 \%$ and the $\mathrm{CO}_{2}$ concentration rose to $5.8 \%$.

Irrigation decreased the $\mathrm{O}_{2}$ concentration and increased the $\mathrm{CO}_{2}$ concentration and they reached their minimum and maximum during the first half of August. These changes were significant already in July (Tables 4 and 5). The minimum $\mathrm{O}_{2}$ concentration (3.4\%) and the maximum $\mathrm{CO}_{2}$ concentration $(9.4 \%)$ were both found at the 


\section{AGRICULTURAL AND FOOD SCIENCE IN FINLAND}

Vol. 7 (1998): 491-505.

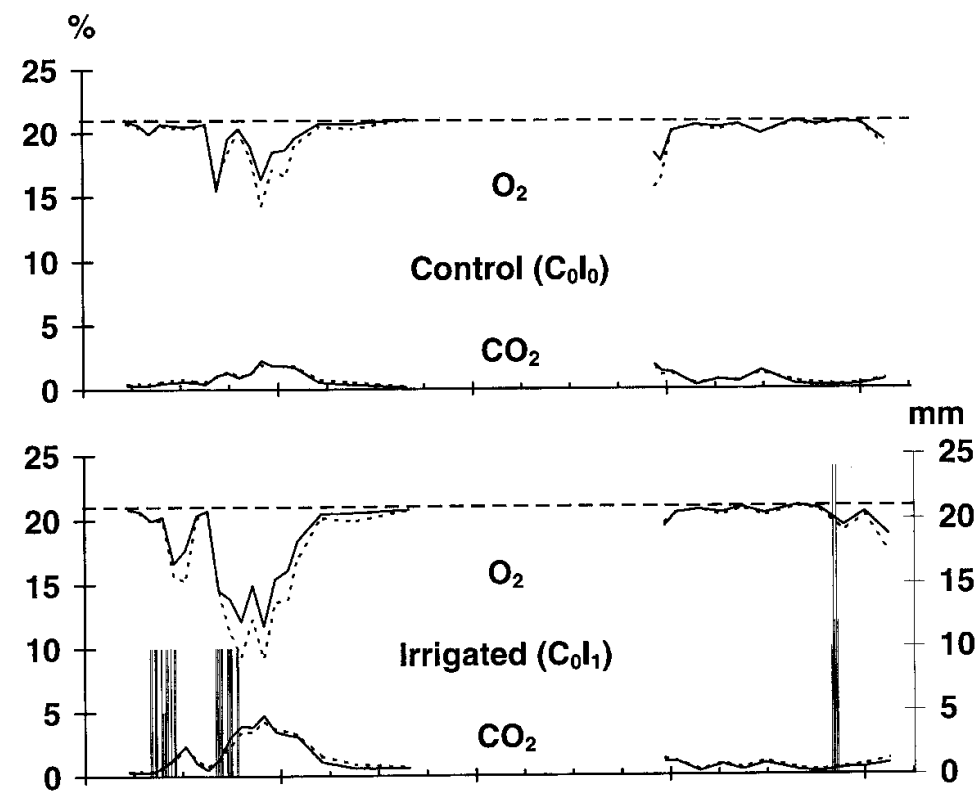

Figure 3. Concentrations (\%) of $\mathrm{O}_{2}$ and $\mathrm{CO}_{2}$ in soil air at depths of 15 (solid line) and $30 \mathrm{~cm}$ (dotted line) and ambient concentration of $\mathrm{O}_{2}$ in the atmosphere (broken line). Columns refer to daily irrigation rate $(\mathrm{mm})$.
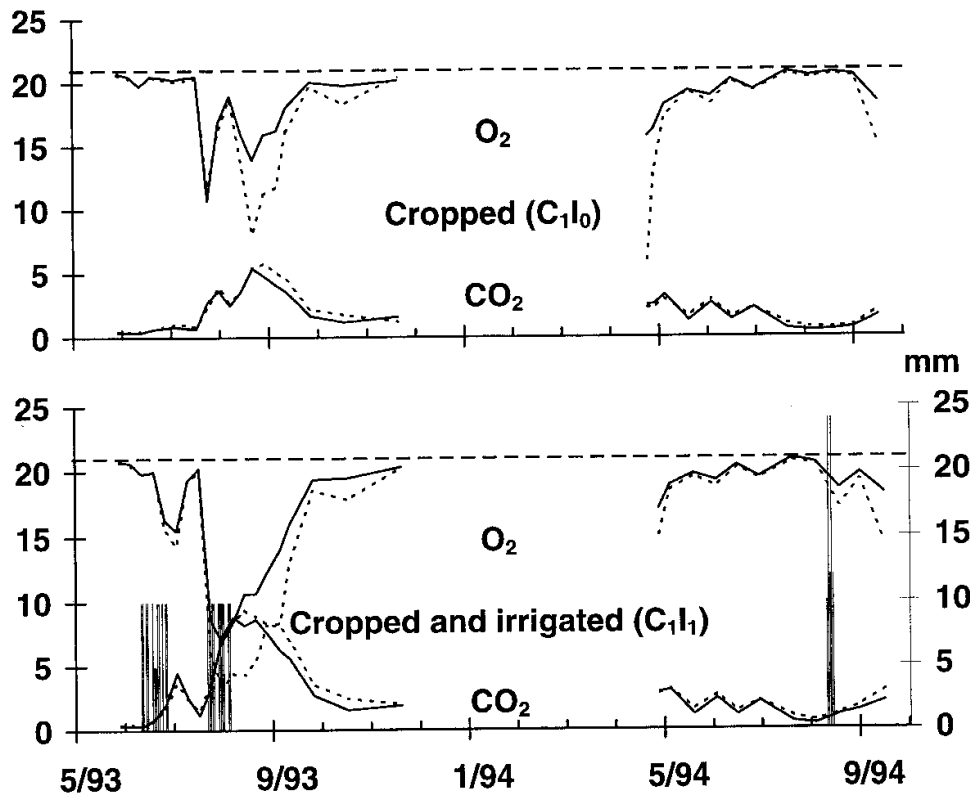

depth of $30 \mathrm{~cm}$ under the crop. The irrigated cropped soil differed from the other treatments, in that the $\mathrm{CO}_{2}$ maximum seemed to take place 1-2 weeks later than the $\mathrm{O}_{2}$ minimum.

Both cropping and irrigation lowered the $\mathrm{O}_{2}$ concentration more strongly deeper in the soil.
A marked difference between the soil depths first appeared in August. In the cropped and irrigated soil the difference lasted until October. The differences in $\mathrm{CO}_{2}$ concentration between the depths were smaller. In the second year the variation of soil air composition was much smaller, 
Jaakkola, A. \& Simojoki, A. Effect of wetness on soil air

Table 4. Average concentration of $\mathrm{O}_{2}$ in the soil air at two depths during various periods, and concentration increase due to treatments, $\%$.

\begin{tabular}{lcccccc}
\hline & \multicolumn{2}{c}{$27.6 .-11.7 .1993$} & \multicolumn{2}{c}{$1.8 .-15.8 .1993$} & \multicolumn{2}{c}{$22.8 .-19.9 .1994$} \\
\hline Treatment & $15 \mathrm{~cm}$ & $30 \mathrm{~cm}$ & $15 \mathrm{~cm}$ & $30 \mathrm{~cm}$ & $15 \mathrm{~cm}$ & $30 \mathrm{~cm}$ \\
\cline { 2 - 7 } Control & 20.6 & 20.4 & $19.6^{\mathrm{c}}$ & $18.8^{\mathrm{c}}$ & 20.4 & 20.3 \\
Irrigated & 18.2 & 17.0 & $13.7^{\mathrm{b}}$ & $11.0^{\mathrm{b}}$ & 19.6 & 18.8 \\
Cropped & 20.4 & 20.3 & $17.3^{\mathrm{bc}}$ & $16.3^{\mathrm{bc}}$ & 19.9 & 18.8 \\
Cropped + irrigated & 17.0 & 16.4 & $8.7^{\mathrm{a}}$ & $4.1^{\mathrm{a}}$ & 18.9 & 17.0 \\
Effect of treatment & & & & & & \\
Cropping & -0.7 & -0.4 & $-3.6^{* * *}$ & $-4.7^{*}$ & $-0.6^{*}$ & -1.6 \\
Irrigation & $-2.8^{* * *}$ & $-3.6^{* * *}$ & $-7.3^{* * *}$ & $-10.0^{* * *}$ & $-0.9^{* * *}$ & -1.7 \\
N-fertilization & -0.1 & -0.1 & 0.3 & -0.6 & 0.1 & 0.5 \\
\hline
\end{tabular}

Significance of effects: $*=\mathrm{P}<0.05, * *=\mathrm{P}<0.01, * * *=\mathrm{P}<0.001$

Table 5. Average concentration of $\mathrm{CO}_{2}$ in the soil air at two depths during various periods, and concentration increase due to treatments, $\%$.

\begin{tabular}{lcccccc}
\hline & \multicolumn{2}{c}{$27.6 .-11.7 .1993$} & \multicolumn{2}{c}{$1.8 .-15.8 .1993$} & \multicolumn{2}{c}{$22.8 .-19.9 .1994$} \\
\hline Treatment & $15 \mathrm{~cm}$ & $30 \mathrm{~cm}$ & $15 \mathrm{~cm}$ & $30 \mathrm{~cm}$ & $15 \mathrm{~cm}$ & $30 \mathrm{~cm}$ \\
\cline { 2 - 7 } Control & $0.58^{\mathrm{a}}$ & $0.73^{\mathrm{a}}$ & $1.16^{\mathrm{a}}$ & $1.31^{\mathrm{a}}$ & 0.40 & 0.47 \\
Irrigated & $1.60^{\mathrm{ab}}$ & $1.59^{\mathrm{ab}}$ & $3.61^{\mathrm{b}}$ & $3.09^{\mathrm{a}}$ & 0.63 & 0.88 \\
Cropped & $0.77^{\mathrm{a}}$ & $0.94^{\mathrm{a}}$ & $3.26^{\mathrm{ab}}$ & $3.44^{\mathrm{a}}$ & 0.92 & 1.21 \\
Cropped + irrigated & $2.99^{\mathrm{b}}$ & $2.60^{\mathrm{b}}$ & $8.15^{\mathrm{c}}$ & $8.26^{\mathrm{b}}$ & 1.56 & 2.02 \\
Effect of treatment & & & & & & \\
Cropping & $0.79^{* * * *}$ & $0.61^{* *}$ & $3.32^{* * *}$ & $3.65^{* * *}$ & $0.73^{* * * *}$ & $0.94^{* * * *}$ \\
Irrigation & $1.62^{* * *}$ & $1.26^{* * *}$ & $3.67^{* * *}$ & $3.30^{* * *}$ & $0.44^{*}$ & $0.61^{* *}$ \\
N-fertilization & -0.05 & 0.05 & -0.38 & -0.18 & -0.20 & -0.25 \\
\hline
\end{tabular}

Treatment means followed by a common letter do not differ significantly $(\mathrm{P}=0.05)$

Significance of effects: $*=\mathrm{P}<0.05$, $* *=\mathrm{P}<0.01$, $* * *=\mathrm{P}<0.001$

being largest in the spring. Thus, even the crop had its biggest effect at the beginning of growing season. Irrigation performed in late summer also had only a small but significant effect on soil air $\mathrm{O}_{2}$ and $\mathrm{CO}_{2}$ (Tables 4 and 5).

$\mathrm{N}$ application did not have any significant effects on $\mathrm{O}_{2}$ concentration (Table 4 ) or $\mathrm{CO}_{2}$ concentration (Table 5) in soil air at either depth.

The $\mathrm{O}_{2}$ concentration in the soil air decreased in the ploughed layer to below $15 \%$ only when the volumetric soil moisture exceeded $30 \%$ (Fig. 4).

The concentration of $\mathrm{CH}_{4}$ in the soil air varied between 0 and $43 \mu 11^{-1}$ independent of treat- ment or sampling date (data not shown). The concentration of $\mathrm{C}_{2} \mathrm{H}_{4}$ did not exceed the detection limit of $0.5 \mu \mathrm{l} \mathrm{l}^{-1}$ in any sample (data not shown).

The concentration of $\mathrm{N}_{2} \mathrm{O}$ in bare, unirrigated soil (control treatment, $\mathrm{C}_{0} \mathrm{I}_{0}$, Fig. 5) varied at various depths and $\mathrm{N}$ rates between 0.4 and 27 $\mu \mathrm{l}^{-1}$ in the first year. In the second year, the range was between 0.4 and $100 \mu 11^{-1}$, but the concentrations did not exceed $7 \mu \mathrm{l}^{-1}$ after May. The peak concentration in 1993 took place by the end of August; higher values were found deeper in the soil. $\mathrm{N}$ application raised the peak. The irrigation in June 1993 raised the concentrations for 
Vol. 7 (1998): 491-505.
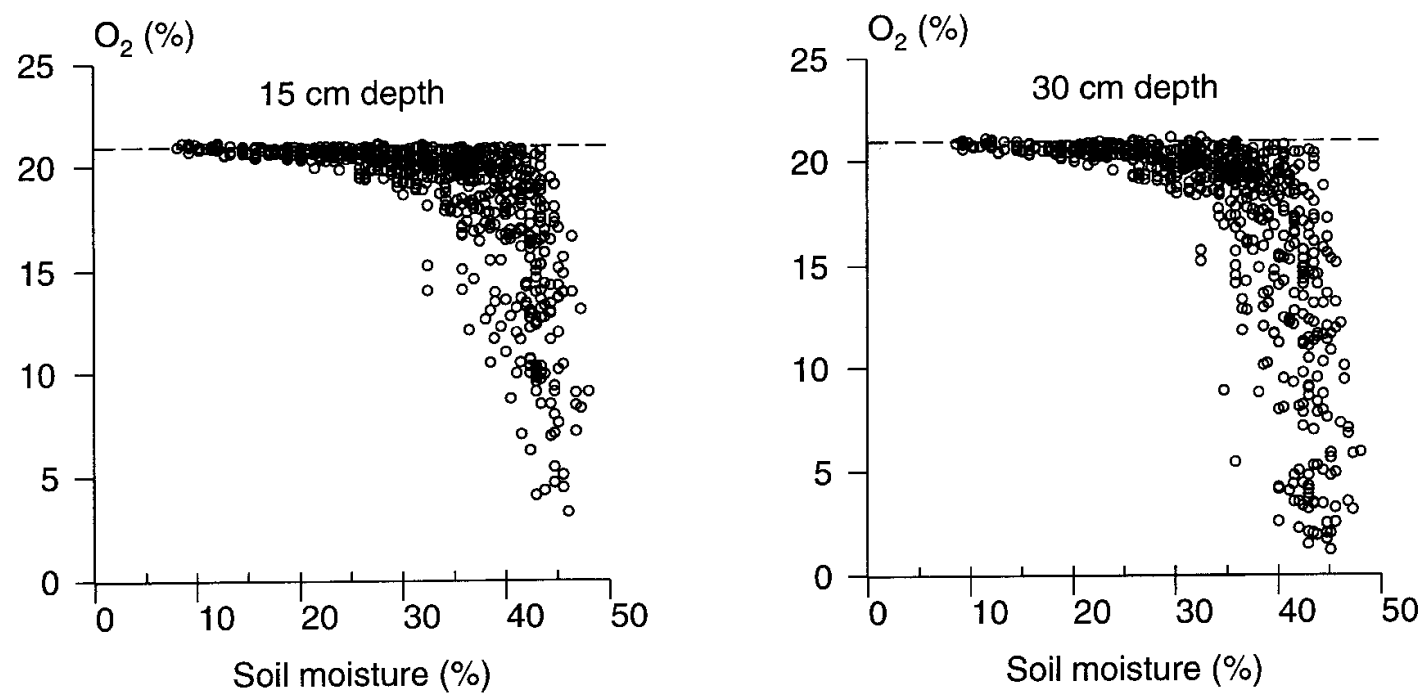

Figure 4. $\mathrm{O}_{2}$ concentration in soil air at various depths plotted against volumetric soil moisture $(0-20 \mathrm{~cm}$ layer, all observations) and ambient concentration of $\mathrm{O}_{2}$ in the atmosphere (broken line).

a couple of weeks (Fig. 5, Table 6). An increase was apparent also during the irrigation period in July-August 1993, but in bare soil only. $\mathrm{N}$ application resulted in greater increases. Neither irrigation nor $\mathrm{N}$ application affected soil air $\mathrm{N}_{2} \mathrm{O}$ in the second year.

In cropped unirrigated soil $\left(\mathrm{C}_{1} \mathrm{I}_{0}\right.$, Fig. 5) the temporal variation of $\mathrm{N}_{2} \mathrm{O}$ was between 0.3 and $3.3 \mu \mathrm{l} \mathrm{l}^{-1}$ in the first year. Without $\mathrm{N}$ application the minimum was achieved by the end of $\mathrm{Au}$ gust 1993. $\mathrm{N}$ application smoothed this trough; otherwise fertilization had no effect. The first irrigation raised $\mathrm{N}_{2} \mathrm{O}$, but the second did not. Towards the end of August 1993 the $\mathrm{N}_{2} \mathrm{O}$ concentration in the air of cropped soil dropped more with irrigations than without (Fig. 5, Table 6), reaching a minimum of $0.2 \mu \mathrm{l} \mathrm{l}^{-1}$. The decrease was not levelled out by $\mathrm{N}$ application.

The mean $\mathrm{N}_{2} \mathrm{O}$ emission of the whole field varied at different sampling times from 0 to $40 \mathrm{~g}$ $\mathrm{N} \mathrm{ha}^{-1} \mathrm{~d}^{-1}$. The mean daily emission over the whole observation period was $7 \mathrm{~g} \mathrm{~N} \mathrm{ha}^{-1} \mathrm{~d}^{-1}$. The differences between treatments could not be tested because there were no replicates. The correlation coefficients between the daily $\mathrm{N}_{2} \mathrm{O}$ emissions on each plot and the corresponding $\mathrm{N}_{2} \mathrm{O}$ concentrations in soil air at depths of 15 and 30 $\mathrm{cm}$ were $0.80(\mathrm{P}<0.001)$ and $0.65(\mathrm{P}<0.001)$, respectively, based on the total material of 234 observations.

\section{Discussion}

In a soil not suffering from extreme wetness due to irrigation the concentrations of $\mathrm{O}_{2}$ ranged from $14 \%$ to $21 \%$, and those of $\mathrm{CO}_{2}$ from $0.1 \%$ to $2 \%$, respectively. This agrees rather well with other studies done in similar conditions (Lindström and McAfee 1989, McAfee et al. 1989a,b, Hansen and Bakken 1993). The minimum mean concentrations of $\mathrm{O}_{2}$ during a fortnight under grass in wet soil after heavy irrigation were $7 \%$ and $3 \%$ at depths of 15 and $30 \mathrm{~cm}$, respectively. These were clearly less than the minimum reported by McAfee et al. (1989a), reaching $11 \%$ at depths of $20-30 \mathrm{~cm}$ in an irrigated clay soil in Sweden, and Hansen and Bakken (1993), who reported a minimum of $13 \%$ at depths of $7-12$ $\mathrm{cm}$ in compacted sandy loam in Norway. Com- 
Jaakkola, A. \& Simojoki, A. Effect of wetness on soil air

$\mu \mathrm{I}^{-1} \quad$ Depth $15 \mathrm{~cm}$
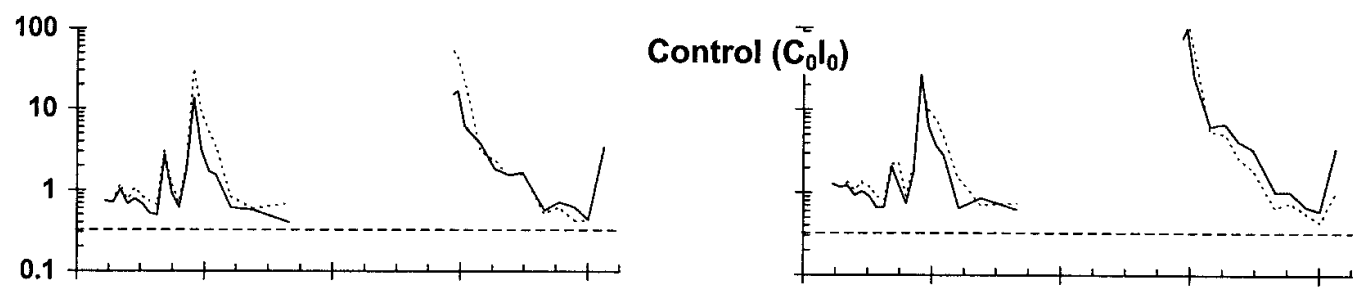

$\mathrm{mm}$
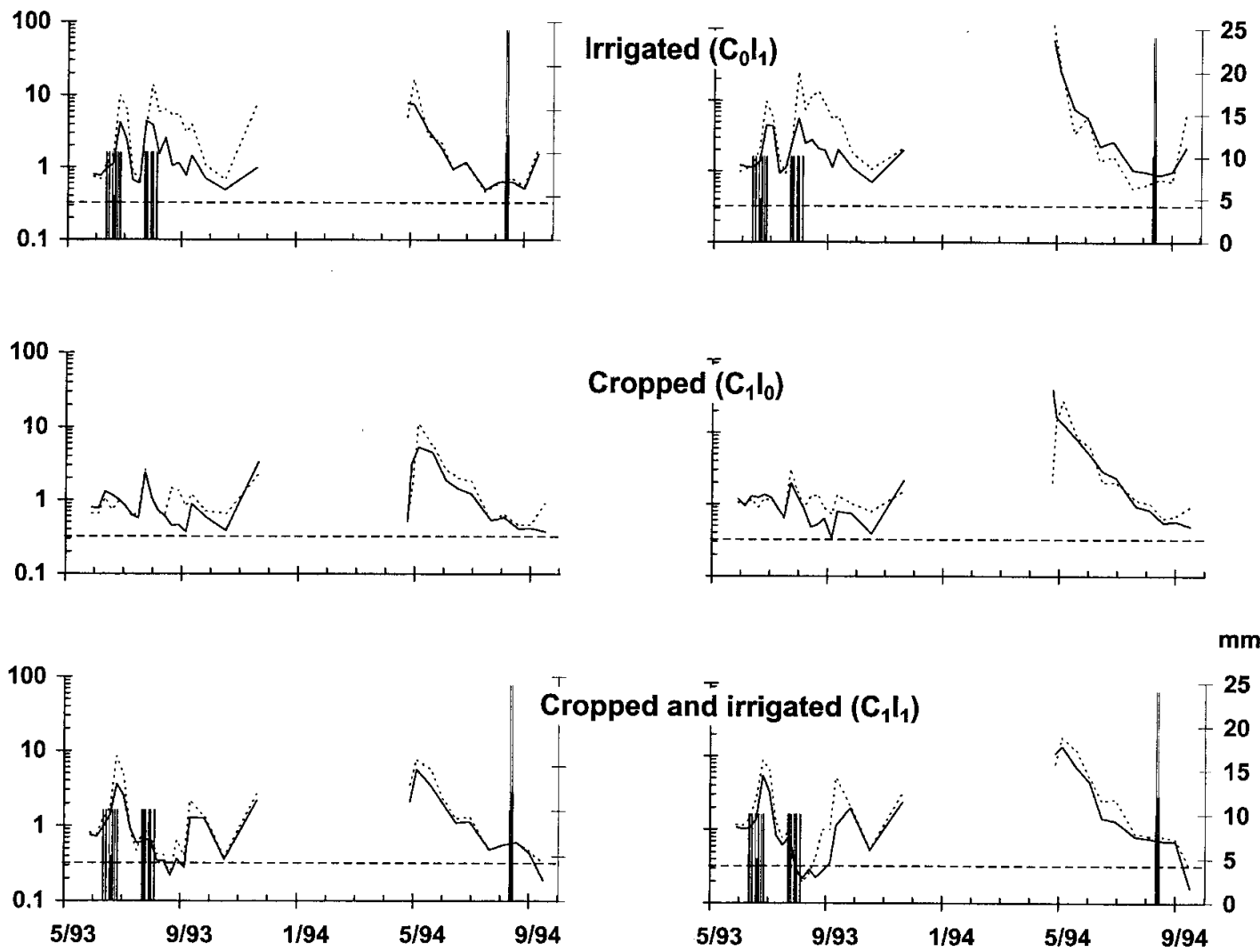

Figure 5. Concentration $\left(\mathrm{Hl} \mathrm{l}^{-1}\right)$ of $\mathrm{N}_{2} \mathrm{O}$ in unfertilized (solid line) and fertilized ( $100 \mathrm{~kg} / \mathrm{ha} \mathrm{N}$, dotted line) soils at depths of 15 and $30 \mathrm{~cm}$, as well as ambient concentration of $\mathrm{N}_{2} \mathrm{O}$ in the air ca. $15 \mathrm{~cm}$ above soil surface (broken line). Columns refer to daily irrigation rate $(\mathrm{mm})$.

paction of a clay loam soil in Finland caused a decrease of $\mathrm{O}_{2}$ concentration to $13 \%$ at a depth of $25 \mathrm{~cm}$ (Simojoki et al. 1991). A minimum of $6 \%$ was reached in their study at a depth of 50 $\mathrm{cm}$. In the present study, the $\mathrm{CO}_{2}$ concentration was raised by heavy irrigation to $9 \%$ at both depths (15 and $30 \mathrm{~cm}$ ). McAfee et al. (1989a) reported a maximum $\mathrm{CO}_{2}$ concentration of $2 \%$ and $4 \%$ after irrigation at depths of 10 and 30 $\mathrm{cm}$, respectively. The maximum concentration of 
Vol. 7 (1998): 491-505.

Table 6. Average (geometric mean) concentration of $\mathrm{N}_{2} \mathrm{O}$ in the soil air at two depths during various periods, $\mu 11^{-1}$, and ratio (effect of treatment) between treated and untreated soils.

\begin{tabular}{lcccccccc}
\hline & \multicolumn{2}{c}{$27.6-11.7 .1993$} & \multicolumn{2}{c}{$1.8 .-15.8 .1993$} & $22.8 .-5.9 .1993$ & \multicolumn{2}{c}{$22.8 .-19.9 .1994$} \\
\hline Treatment & $15 \mathrm{~cm}$ & $30 \mathrm{~cm}$ & $15 \mathrm{~cm}$ & $30 \mathrm{~cm}$ & $15 \mathrm{~cm}$ & $30 \mathrm{~cm}$ & $15 \mathrm{~cm}$ & $30 \mathrm{~cm}$ \\
\cline { 2 - 9 } Control & 0.75 & 0.98 & $1.09^{\mathrm{ab}}$ & $1.38^{\mathrm{b}}$ & 6.86 & 10.02 & 0.91 & 0.83 \\
Irrigated & 2.67 & 3.36 & $4.44^{\mathrm{b}}$ & $6.54^{\mathrm{c}}$ & 2.09 & 3.91 & 0.83 & 1.27 \\
Cropped & 0.79 & 1.08 & $0.77^{\mathrm{a}}$ & $0.98^{\mathrm{ab}}$ & 0.73 & 0.54 & 0.48 & 0.63 \\
Cropped + irrigated & 2.56 & 3.14 & $0.44^{\mathrm{a}}$ & $0.26^{\mathrm{a}}$ & 0.33 & 0.47 & 0.41 & 0.49 \\
Effect of treatment & & & & & & & & \\
Cropping & 1.01 & 1.01 & $0.26^{* * *}$ & $0.17^{* * *}$ & $0.13^{* * *}$ & $0.08^{* * *}$ & $0.51^{* * *}$ & $0.54^{* * *}$ \\
Irrigation & $3.40^{* * *}$ & $3.17^{* * *}$ & $1.52^{* *}$ & $1.12^{*}$ & $0.37^{*}$ & 0.58 & 0.89 & 1.09 \\
N-fertilization & $1.41^{*}$ & $1.35^{*}$ & 1.46 & 1.60 & $2.54^{*}$ & 2.51 & 1.15 & 1.07 \\
\hline
\end{tabular}

Treatment means followed by a common letter do not differ significantly $(\mathrm{P}=0.05)$

Significance of effects: $*=\mathrm{P}<0.05, * *=\mathrm{P}<0.01$, $* * *=\mathrm{P}<0.001$

$\mathrm{CO}_{2}$ caused by compaction in the trial of Simojoki et al. (1991) was 5\% at depths of 25 and 50 $\mathrm{cm}$, but it lasted longer deeper in the soil. In the experiment of Hansen and Bakken (1993) a maximum $\mathrm{CO}_{2}$ concentration of almost $5 \%$ at depths of 7-12 cm was caused by soil compaction.

Soil respiration consuming $\mathrm{O}_{2}$ and producing $\mathrm{CO}_{2}$ was, no doubt, the most important phenomenon altering soil air composition in the present experiment. Respiration in cropped soil was probably 2-3 times higher than in uncropped soil (Currie 1975). In the first year, irrigation and $\mathrm{N}$ fertilization improved plant growth, which in turn probably also increased soil respiration. On the other hand, if plant water uptake had increased air-filled porosity, the enhanced gas exchange would have counteracted the effects of respiration. But since cropping and $\mathrm{N}$ fertilization had only minor effects on soil moisture in this experiment, the significant effects of cropping on $\mathrm{O}_{2}$ and $\mathrm{CO}_{2}$ concentrations in soil air were mainly due to differences in respiration. Hansen and Bakken (1993) also found no effect of $\mathrm{N}$ fertilization in sandy loam under ley. In contrast, Stępniewski (1977), working with several plant species, found that doubling the mineral fertilizer dose improved soil aeration status in a cropped loamy sand soil.
Soil air composition deviated from atmospheric air composition most during a period of very high moisture content in soil simultaneously with high temperature, occurring in July-August 1993. In wet soil, under a vigorously growing, oxygen-consuming plant, the $\mathrm{O}_{2}$ concentration in soil air at the bottom of plough layer dropped below 4\%. The concentration increased again during the second half of August and thereafter, although no marked increase in air-filled porosity occurred. Obviously the decreased consumption of oxygen allowed this increase. A similarly decreasing deviation from atmospheric air towards the end of growing season was observed e.g. by Simojoki et al. (1991) in a pot experiment with barley. In their study, decreasing respiration could have been related mainly to the developmental stage of the plant. However, in the present study the influences of oxygen deficiency, due to its low content in soil air, and of simultaneously decreasing temperature were most obvious, because similar changes were observed in both bare and cropped soils. In addition, the respiration rate in grass does not change remarkably with development stage as in cereals. Soil respiration is generally regarded as an exponential function of temperature (Gliński and Stępniewski 1985). Yearly variations in soil res- 


\section{Jaakkola, A. \& Simojoki, A. Effect of wetness on soil air}

piration mainly due to temperature fluctuations are well known (Currie 1975).

The decrease of $\mathrm{O}_{2}$ was connected with an increase in $\mathrm{CO}_{2}$. However, they were not equivalent, the former being bigger than the latter. This difference has been observed in many other studies (e.g. Russell and Appleyard 1915, Gliński and Stępniewski 1973, 1985) and is explained by the rather high solubility in water of $\mathrm{CO}_{2}$ as compared with that of $\mathrm{O}_{2}$. If there had been strong anaerobic production of $\mathrm{CO}_{2}$ in the soil, the sum of $\mathrm{O}_{2}$ and $\mathrm{CO}_{2}$ would have exceeded $21 \%$ (Gliński and Stępniewski 1973). Probably, $\mathrm{CH}_{4}$ concentration would have also increased. In the present study, increases in the $\mathrm{CH}_{4}$ concentration and in the sum of $\mathrm{O}_{2}$ and $\mathrm{CO}_{2}$ concentration were never observed.

The difference of $\mathrm{O}_{2}$ concentration between depths was many times larger than the corresponding difference of $\mathrm{CO}_{2}$ concentration. This is partly explained by the better solubility of $\mathrm{CO}_{2}$ in water, but the more rapid diffusion of $\mathrm{CO}_{2}$ in soil water may also play a role (Greenwood 1970).

A plant hormone $\mathrm{C}_{2} \mathrm{H}_{4}$ is involved in plant response to hypoxia (see Jackson 1991). In relatively wet soils concentrations of several $\mu 1 \mathrm{l}^{-1}$ have been observed both in field (Dowdell et al. 1972, Smith and Dowdell 1974) and pot experiments (Simojoki et al. 1991), although variation has been great. In contrast, no $\mathrm{C}_{2} \mathrm{H}_{4}$ was found in soil air in the present study. In other investigations low concentrations $\left(0.5 \mu 11^{-1}\right.$ or less $)$ have been measured in aerobic soils (Otani \& Ae 1993), but sometimes also in wet soils (Meek et al. 1986). Taken together the results suggest that $\mathrm{C}_{2} \mathrm{H}_{4}$ is not a sensitive indicator of hypoxia in soil.

The $\mathrm{N}_{2} \mathrm{O}$ concentrations $\left(0.2-100 \mu 11^{-1}\right)$ were in the range reported by Hansen and Bakken (1993) in the topsoil of Norwegian field experiment on a sandy loam with different soil compaction and fertilization treatments. In the present experiment the highest concentrations (May 1994) were probably caused by the spring thaw (see Nyborg et al. 1997).

At the beginning of the experiment a lot of nitrate was present in both non-fertilized and fertilized plots. By the end of the first irrigation period no effect of cropping on $\mathrm{N}_{2} \mathrm{O}$ in soil air was found; however irrigation had increased the concentration markedly and $\mathrm{N}$ application had done so to some extent. Soon thereafter cropping started to decrease $\mathrm{N}_{2} \mathrm{O}$ in soil air as a consequence of decreased nitrate in the soil due to uptake by plants. Cropping still affected $\mathrm{N}_{2} \mathrm{O}$ in soil air in the second year, while the other treatments did not. Irrigation probably caused losses of soil nitrate by denitrification and leaching. As a consequence, the high concentration of $\mathrm{N}_{2} \mathrm{O}$ in bare soil in the first autumn was markedly lowered by irrigation. Heterotrophic denitrification by bacteria is the most probable source of $\mathrm{N}_{2} \mathrm{O}$ in the conditions prevailing in the present experiment (see Granli and Bøckman 1994). Nitrification probably also contributed to $\mathrm{N}_{2} \mathrm{O}$ production, since the concentration of $\mathrm{N}_{2} \mathrm{O}$ in soil air was generally higher than the ambient level even when the soil was not wet (Bremner and Blackmer 1978). When the soil was very wet due to irrigation and soil nitrate was depleted by the crop, lower than ambient concentrations were found, suggesting that $\mathrm{N}_{2} \mathrm{O}$ was reduced to $\mathrm{N}_{2}$ more rapidly than $\mathrm{N}_{2} \mathrm{O}$ was produced by denitrification or diffused from the atmosphere to the soil.

$\mathrm{N}$ application increased $\mathrm{N}_{2} \mathrm{O}$ in soil air during several periods throughout the first growing season. The increases were largest in bare soil, when it was wet either due to irrigation or rain. The biggest increase during a fortnight was on average 2.5 -fold. This compares well with the results of Hansen and Bakken (1993) in uncompacted soil. They reported a much higher (100fold) increase due to mineral $\mathrm{N}$ application in compacted soil only.

The emissions of $\mathrm{N}_{2} \mathrm{O}$ were in the range reported in other studies made in comparable conditions with similar methods (e.g. Kaiser et al. 1996, MacKenzie et al. 1997). Substantially higher emissions were observed only occasionally in their studies. The correlation between emission and $\mathrm{N}_{2} \mathrm{O}$ in soil air was expectedly better at a depth of $15 \mathrm{~cm}$ than deeper in the soil. 
Vol. 7 (1998): 491-505.

An air-filled porosity of $10 \% \mathrm{v} / \mathrm{v}$ is commonly regarded as critical for the satisfaction of the oxygen demand of the crop (Wesseling 1974). However, the actual critical value depends on oxygen consumption rate, pore size and pore continuity in the soil, and will therefore change with microbial activity, temperature, vegetation, soil type and soil structure. Values from $8 \%$ to $15 \%$ have been reported (Wesseling 1974, Hodgson and MacLeod 1989, Chan and Hodgson 1995). There are also cases where no critical value could be determined (Chan and Hodgson 1995).

Assuming that the soil was water-saturated during the rather long period of wetness in the first year, an estimate (probably an underestimate) of total porosity is $43-45 \%$. It is almost certain that in the present study plant growth was not affected by the limited gas exchange when the soil moisture was below $30 \%$ v/v. This corresponded to air-filled porosities of at least 13$15 \% \mathrm{v} / \mathrm{v}$. Periods of limited gas exchange according to the adopted criterion were in the unirrigated soil from the middle of July onwards in the first year and until the middle of June in the second year. In the irrigated soil there was shortage of air-filled porosity already in the latter part of June. The irrigation in August of the second year caused a period of restricted gas exchange after the middle of August. The periods referred to above agree quite well with the periods of decreased $\mathrm{O}_{2}$ and increased $\mathrm{CO}_{2}$ concentrations. The agreement with elevated $\mathrm{N}_{2} \mathrm{O}$ concentrations is also reasonably good, if the existence of nitrate in the soil is also considered.

In conclusion, it can be stated that in the conditions prevailing in southern Finland the $\mathrm{O}_{2}$ in soil air might be markedly decreased in wet periods. Especially under crop stands the $\mathrm{O}_{2}$ concentration may drop substantially to a level where the plants, if the low concentration persists, may suffer from $\mathrm{O}_{2}$ deficiency (see Glínski and Stępniewski 1985, Jaakkola et al. 1990). Increases of $\mathrm{CO}_{2}$, although occasionally very large, probably do not reach detrimental levels. In wet soil, denitrification causing losses of nitrate $\mathrm{N}$ and increasing $\mathrm{N}_{2} \mathrm{O}$ emission is obvious. Marked increases of $\mathrm{CH}_{4}$ or $\mathrm{C}_{2} \mathrm{H}_{4}$ in soil air do not seem to be probable in the conditions of the present study.

Acknowledgements. We thank Dr. Delbert Mokma (Michigan State University, USA) for soil classification, the Agricultural Research Centre for analysing the soil extracts, the Finnish Meteorological Institute for providing the precipitation data, and Henry Fullenwider for revising the text. The financial support from the Academy of Finland is gratefully acknowledged.

\section{References}

Bremner, J.M. \& Blackmer, A.M. 1978. Nitrous oxide: Emission from soils during nitrification of fertilizer nitrogen. Science 199: 295-296.

Chan, K.Y. \& Hodgson, A.S. 1995. Subsoil structure changes of a typic Pellustert under dryland cropping. Soil Science 160: 376-383.

Currie, J. 1975. Soil respiration. Ministry of Agriculture, Fisheries and Food, Technical Bulletin 29: 461-468.

Dowdell, R.J., Smith, K.A., Crees, R. \& Restall S.W.F. 1972. Field studies of ethylene in the soil atmosphere - equipment and preliminary results. Soil Biology and Biochemistry 4: 325-331.

Gliński, J. \& Stẹpniewski, W. 1973. The influence of different substances on the accumulation of high $\mathrm{CO}_{2}$ concentrations in soils. Polish Journal of Soil Science 6: $63-70$.
- \& Stepniewski, W. 1985. Soil Aeration and Its Role for Plants. Boca Raton, Florida, CRC Press. 229 p.

Granli, T. \& Bøckman, O.C. 1994. Nitrous oxide from agriculture. Norwegian Journal of Agricultural Sciences. Supplement 12. $128 \mathrm{p}$.

Greenwood, D.J. 1970. Distribution of carbon dioxide in the aqueous phase of aerobic soils. Journal of Soil Science 21: 314-329.

Hansen, S. \& Bakken, L.R. 1993. $\mathrm{N}_{2} \mathrm{O}, \mathrm{CO}_{2}$ and $\mathrm{O}_{2}$ concentrations in soil air influenced by organic and inorganic fertilizers and soil compaction. Norwegian Journal of Agricultural Sciences 7: 1-10.

Hodgson, A.S. \& MacLeod, D.A. 1989. Use of oxygen flux density to estimate critical air-filled porosity of a Vertisol. Soil Science Society of America Journal 53: 355-361. 
Jaakkola, A. \& Simojoki, A. Effect of wetness on soil air

Jaakkola, A., Simojoki, A. \& Auramo, J. 1990. Effect of soil air composition on plant growth and nutrient uptake. Transactions of 14th ICSS, IV: 62-65.

Jackson, M.B. 1991. Ethylene in root growth and development. In: Mattoo, A.K. \& Suttle, J.C. (ed.). The plant hormone ethylene. Boca Raton, Florida, CRC Press. p. 159-181.

Kaiser, E.-A., Eiland, F., Germon, J.C., Gispert, M.A., Heinemeyer, O., Henault, C., Lind, A.M., Maag, M., Saguer, E., Van Cleemput, O., Vermoesen, A. \& Webster, C. 1996. What predicts nitrous oxide emissions and denitrification N-loss from European soils? Zeitschrift für Pflanzenernährung und Bodenkunde 159: 541-547.

Lindström, J. \& McAfee M. 1989. Aeration studies on arable soil. 2. The effect of a grass ley or cereal on the structure of a heavy clay. Swedish Journal of Agricultural Research 19: 155-161.

MacKenzie, A.F., Fan, M.X. \& Cadrin, F. 1997. Nitrous oxide emission as affected by tillage, corn-soybeanalfalfa rotations and nitrogen fertilization. Canadian Journal of Soil Science 77: 145-152.

McAfee, M., Lindström, J. \& Johansson, W. 1989a. Aeration changes after irrigation in a clay soil. Journal of Soil Science 40: 719-729.

- , Lindström, J. \& Johansson, W. 1989b. Aeration studies on arable soil. 1. The effect of sand/peat mulch on aeration regime in a silty clay loam. Swedish Journal of Agricultural Research 19: 147-153.
Meek, B.D., Donovan, T.J. \& Graham, L.E. 1986. Alfalfa stand losses from irrigation: influence of soil temperature, texture, and aeration status. Soil Science Society of America Journal 50: 651-655.

Nyborg, M., Laidlaw, J.W., Solberg, E.D. \& Malhi, S.S. 1997. Denitrification and nitrous oxide emissions from a Black Chernozemic soil during spring thaw in Alberta. Canadian Journal of Soil Science 77: 153-160.

Otani, T. \& Ae, N. 1993. Ethylene and carbon dioxide concentrations of soil as influenced by rhizosphere of crops under field and pot conditions. Plant and Soil 150: 255-262.

Russell, E.J. \& Appleyard, A. 1915. The atmosphere of the soil. Journal of Agricultural Science 7: 1-48.

Simojoki, A., Jaakkola, A. \& Alakukku, L. 1991. Effect of compaction on soil air in a pot experiment and in the field. Soil and Tillage Research 19: 175-186.

Smith, K., \& Dowdell, R.J. 1974. Field studies of the soil atmosphere. I. Relationships between ethylene, oxygen, soil moisture content and temperature. Journal of Soil Science 25: 217-230.

Stępniewski, W. 1977. The effect of irrigation and increased mineral fertilization on the aeration status of a cultivated soil. Zeszyty Problemowe Postępów Nauk Rolniczych 197: 203-220.

Wesseling, J. 1974. Crop growth and wet soils. In: Schilfgaarde, J. van (Ed.). Drainage for Agriculture. Agronomy 17. p. 7-37. 
Vol. 7 (1998): 491-505.

\title{
SELOSTUS
}

\section{Maan märkyyden vaikutus ilman koostumukseen ja dityppioksidiemissioon hiuemaassa}

\author{
Antti Jaakkola ja Asko Simojoki \\ Helsingin yliopisto
}

Kaksivuotinen kenttäkoe tehtiin hiuemaalla EteläSuomessa. Faktorikokeen koetekijöinä olivat rankka kastelu ja typpilannoitus. Osa ruuduista oli kasvittomia, osalla kasvoi heinää. Maan ilman koostumusta 15 ja $30 \mathrm{~cm}$ syvyydessä seurattiin yhden tai kahden viikon välein otetuista näytteistä. Myös maan kosteutta (TDR) ja lämpötilaa mitattiin säännöllisesti. Kasvittoman, kastelemattoman ja lannoittamattoman maan ilmassa oli 14-21\% happea, 0,1-2 \% hiilidioksidia ja 0,2-100 $\mu 11^{-1}$ dityppioksidia. Lukuunottamatta toisen vuoden toukokuun kaikkein suurimpia dityppioksidipitoisuuksia, suurin pitoisuus oli $27 \mu \mathrm{l}$ $1^{-1}$. Maan kosteus vaihteli välillä $11-45 \%$ ja lämpötila $15 \mathrm{~cm}$ syvyydessä välillä $0-21^{\circ} \mathrm{C}$. Kasvipeite ja kastelu vähensivät happipitoisuutta ja lisäsivät hiilidioksidipitoisuutta. Happipitoisuus muuttui selvästi enemmän syvemmällä maassa $(30 \mathrm{~cm})$ kuin matalammassa $(15 \mathrm{~cm})$, sen sijaan hiilidioksidipitoisuuden muutos oli syvyydestä riippumaton. Kasvipeitteisen ja kastellun maan pienimmät happipitoisuudet olivat
$7 \%$ (15 cm syvyydessä) ja $3 \%$ (30 cm syvyydessä). Suurimmat hiilidioksidipitoisuudet olivat $9 \%$. Typpilannoitus ei vaikuttanut merkitsevästi maan ilman happi- ja hiilidioksidipitoisuuksiin. Kastelu lisäsi maan ilman dityppioksidipitoisuutta silloin kun maassa oli runsaasti nitraattia. Kasvittomassa maassa oli runsaasti nitraattia jäljellä vielä elokuussa. Typpilannoitus nosti maan ilman dityppioksidipitoisuutta erityisesti kastellussa kasvittomassa maassa. Kasvipeite vähensi dityppioksidipitoisuutta. Maan ilman koostumuksen vaihtelua voitiin osittain selittää arvioidun ilmahuokoisuuden avulla. Muutamalta ruudulta suljetun kammion menetelmällä mitattu koekentän dityppioksidiemissio vaihteli välillä 0-40 $\mathrm{g} \mathrm{N} \mathrm{ha}^{-1} \mathrm{~d}^{-1}$. Kaikkien mittausten keskiarvo oli $7 \mathrm{~g} \mathrm{~N} \mathrm{ha}^{-1} \mathrm{~d}^{-1}$. Emissio korreloi $15 \mathrm{~cm}$ syvyydestä mitatun dityppioksidipitoisuuden kanssa $(\mathrm{r}=0,80 ; \mathrm{n}=234)$ ja $30 \mathrm{~cm}$ syvyydestä mitatun pitoisuuden kanssa $(r=0,65$, $\mathrm{n}=234)$. 